\title{
FANCE wt Allele
}

National Cancer Institute

\section{Source}

National Cancer Institute. FANCE wt Allele. NCI Thesaurus. Code C86552.

Human FANCE wild-type allele is located within 6p22-p21 and is approximately $15 \mathrm{~kb}$ in length. This allele, which encodes Fanconi anemia group E protein, is involved in the mediation of both protein localization and DNA repair. Mutation of the gene is associated with Fanconi anemia. 